\title{
PENERAPAN METODE KOOPERATIF TIPE TAI UNTUK MENINGKATKAN PEMAHAMAN SISWA TERHADAP PEMBELAJARAN MATEMATIKA
}

\author{
Nuraspida \\ Guru SDN 4 Teluk Melano
}

\begin{abstract}
Abstrak: Hasil belajar siswa pada pembelajaran Matematika khususnya pada materi operasi hitung bilangan bulat positif dan negatif tahun pelajaran 2016/2017 sangat rendah. Hal ini dibuktikan berdasarkan hasil evaluasi yang dilakukan guru sekitar $70 \%$ mendapatkan nilai dibawah Kriteria Ketuntasan Minimum yang ditetapkan sekolah untuk pembelajaran Matematika kelas IV yaitu 60. Salah satu faktor yang menjadi penyebab rendahnya hasil belajar siswa adalah ketidaktepatan penggunaan model atau strategi pembelajaran yang digunakan guru dalam menyampaikan materi yang diajarkan di kelas. Hal ini disebabkan karena guru kurang memahami konsepsi siswa dan tidak membangkitkan perubahan konseptual siswa.Untuk mengatasi masalah tersebut dilaksanakannya penelitian tindakan kelas sebagai upaya perbaikan pembelajaran dengan menerapkan metode kooperatif tipe Team Assisted Individualization (TAI) mampu meningkatkan pemahaman siswa terhadap materi operasi hitung bilangan bulat positif dan negatif pada pembelajaran Matematika Kelas IV SDN 4 Teluk Melano semester genap tahun pelajaran 2016/2017. Hasil yang didapat setelah pelaksanaan penelitikan tindakan kelas dengan menerapkan metode kooperatif tipe Team assisted Individualization (TAI) selama 2 siklus penelitian adalah Pada Siklus II jumlah siswa yang mendapatkan nilai diatas KKM pada perbaikan pembelajaran siklus II meningkat dari jumlah yang sebelumnya 10 orang menjadi 14 orang mendapatkan nilai diatas KKM. Pada siklus II ini terjadi pula penurunan jumlah siswa yang mendapatkan nilai dibawah KKM setelah dievaluasi yaitu hanya tinggal 6 orang atau sekitar $30 \%$ dari 20 orang siswa.
\end{abstract}

Kata Kunci : Team,Assisted,Individulization

\section{PENDAHULUAN}

Pada dasarnya pembelajaran merupakan hasil sinergi dari tiga komponen pembelajaran utama yakni siswa, kompetensi guru dan fasilitas pembelajaran. Pembelajaran matematika adalah suatu proses atau kegiatan guru mata pelajaran matematika dalam mengajarkan matematika kepada para siswanya, yang didalamnya terkandung upaya guru untuk menciptakan iklim dan pelayanan terhadap kemampuan potensi, minat, bakat dan kebutuhan siswa tentang matematika yang amat beragam agar terjadi interaksi optimal antara guru dengan siswa serta antara siswa dengan siswa.
Dalam menciptakan iklim suasana dan pelayanan hal yang esensial bagi guru adalah memahami cara-cara siswa memperoleh pengetahuan dari kegiatan belajarnya. Siswa harus mempelajari matematika melalui pemahaman dan aktif membangun pengetahuan baru dari pengalaman dan pengetahuan yang dimiliki sebelumnya. Pembelajaran matematika yang berlangsung dapat berjalan efektif dan menyenangkan jika guru dapat memahami proses perolehan pengetahuan, maka ia dapat menentukan strategi pembelajaran yang tepat bagi siswa. Hal ini merupakan suatu tantangan bagi guru matematika untuk senantiasa berpikir dan bertindak kreatif. 
Selain itu, matematika sekolah berfungsi mengembangkan kemampuan berhitung, menurunkan dan menggunakan rumus diantaranya melalui materi pengukuran dan geometri, aljabar dan trigonometri. Matematika juga berfungsi mengembangkan kemampuan mengkomunikasikan gagasan dengan bahasa melalui model matematika yang dapat berupa kalimat dan persamaan matematika, diagram, grafik atau table ( dalam Ningsih, 2008 :22). Matematika sebagai alat bernalar sangat berperan dalam penerapannya kebidang studi lainnya. Adapun tujuan pembelajaran matematika adalah sebagai berikut :

1. Melatih cara berpikir dan bernalar dalam menarik kesimpulan, misalnya melalui kegiatan penyelidik, eksplorasi, eksperimen, menunjukkan kesamaan, perbedaan, konsisten dan inkonsisten.

2. Mengembangkan aktivitas kreatif yang melibatkan imajinasi, intuisi dan penemuan dengan mengembangkan pemikiran divergen, orisinil, rasa ingin tahu, membuat prediksi dan dugaan serta mencoba-coba.

3. Mengembangkan kemampuan memecahkan masalah.

4. Mengembangkan kemampuan menyampaikan informasi atau mengkomunikasikan gagasan, antara lain melalui pembicaraan lisan, catatan, grafik, peta dan diagram.

(Lambas dkk, 2004:18)

Jadi pembelajaran matematika adalah usaha sadar guru untuk membantu siswa dengan sebaik-baiknya, agar mereka dapat belajar ilmu bilangan dan prosedur operasional yang digunakan dalam menyelesaikan masalah mengenai bilangan sesuai dengan kebutuhan dan minatnya.

Model pembelajaran kooperatif adalah model pembelajaran yang didalamnya mengkondisikan para siswa bekerja bersama-sama didalam kelompokkelompok kecil untuk membantu satu sama lain dalam belajar. Pembelajaran kooperatif didasarkan pada gagasan atau pemikiran bahwa siswa bekerja bersamasama dalam belajar, dan bertanggung jawab terhadap aktivitas belajar kelompok mereka seperti terhadap diri mereka sendiri.

Menurut Muslimin Ibrahim (2001:7) model pembelajaran kooperatif dikembangkan untuk mencapai tiga tujuan penting, yaitu :

1.) Hasil belajar akademik

Model pembelajaran kooperatif dapat membantu siswa memahami konsep-konsep yang sulit. Disamping mengubah norma yang berhubungan dengan hasil belajar, pembelajaran kooperatif dapat memberi keuntungan baik pada siswa kelompok bawah maupun kelompok atas yang bekerja sama dalam meyelesaikan tugas-tugas akademik

2.) Penerimaan Terhadap Keragaman Efek penting dari pembelajaran kooperatif adalah penerimaan yang luas terhadap orang lain yang berbeda ras, budaya, kelas ekonomi, kemampuan maupun ketidak mampuan. Pembelajaran kooperatif memberi peluang kepada siswa yang berbeda latar belakang dan kondisi untuk saling bergantung satu sama lain atas tugas-tugas bersama, dan belajar untuk menghargai satu sama lain.

3.) Pengembangan Keterampilan Sosial

Tujuan ketiga dari pembelajaran kooperatif adalah untuk mengajarkan kepada siswa keterampilan kerjasama dan kolaborasi. Keterampilan ini amat penting untuk dimiliki dalam 
masyarakat dimana banyak kerja orang dewasa sebagian besar dilakukan dalam organisasi yang saling bergantung satu sama lain dan dimana masyarakat secara budaya semakin beragam.

Tabel 2

Langkah-langkah model pembelajaran

Kooperatif

\begin{tabular}{lll}
\hline \multicolumn{1}{c}{ FASE } & \multicolumn{2}{c}{ TINGKAH LAKU GURU } \\
\hline $\begin{array}{l}\text { 1. Menyampaikan tujuan dan } \\
\text { memotivasi siswa }\end{array}$ & $\begin{array}{l}\text { Guru menyampaikan semua tujuan } \\
\text { pembelajaran yang ingin dicapai pada } \\
\text { pembelajaran tersebut. }\end{array}$ \\
\hline 2. Menyajikan informasi & $\begin{array}{l}\text { Guru menyampaikan informasi kepada } \\
\text { siswa dengan jalan demonstrasi atau } \\
\text { lewat bahan bacaan }\end{array}$ \\
\hline $\begin{array}{l}\text { 3. Mengorganisasikan siswa } \\
\text { kedalam kelompok-kelompok } \\
\text { belajar }\end{array}$ & $\begin{array}{l}\text { Guru membentuk kelompok belajar } \\
\text { siswa dan memantau setiap kelompok } \\
\text { agar pelaksanaan tugas teratur }\end{array}$ \\
\hline 4. Membimbing kelompok & $\begin{array}{l}\text { Guru membimbing kelompok- } \\
\text { kekerja dan belajar }\end{array}$ & $\begin{array}{l}\text { kelompok belajar pada saat mereka } \\
\text { mengerjakan tugas-tugas } \\
\text { diberikan yang }\end{array}$ \\
& $\begin{array}{l}\text { Guru mengevaluasi hasil belajar } \\
\text { tentang materi yang telah dipelajari } \\
\text { dan masing-masing kelompok } \\
\text { mempresentasikan hasil kerja mereka }\end{array}$ \\
\hline 5. Evaluasi & $\begin{array}{l}\text { Guru mencari cara-cara untuk } \\
\text { menghargai baik upaya maupun hasil }\end{array}$ \\
& belajar individu dan kelompok
\end{tabular}

Menurut Slavin (2009:22) Pembelajaran kooperatif ini akan memberi manfaat bagi peserta didik dengan adanya peningkatan hasil belajar dan kemampuan kognitif peserta didik. Jika dilakukan dengan sempurna setiap peserta didik akan mempunyai tanggung jawab untuk tugasnya masing-masing serta berpeluang mempunyai pengetahuan yang lain melalui kelompok yang berbeda.

Menurut Johnson (dalam Retna Kusumaningrum, 2007 : 17) menunjukkan adanya berbagai keunggulan pembelajaran kooperatif antara lain sebagai berikut :

1.) Memudahkan siswa melakukan penyesuaian sosial

2.) Mengembangkan kegembiraan belajar yang sejati.

3.) Memungkinkan para siswa saling belajar mengenai sikap, keterampilan, informasi, perilaku sosial dan pandangan.

4.) Menghilangkan sifat mementingkan diri sendiri atau egois dan egosentris.

5.) Meningkatkan rasa saling percaya kepada sesama manusia. 
6.) Meneningkatkan kesediaan menggunakan ide orang lain yang dirasakan lebih baik.

7.) Meningkatkan motivasi belajar instrinsik.

8.)Meningkatkan sikap positif terhadap belajar dan pengalaman belajar.

Pembelajaran kooperatif tipe Team Assisted Individualization (TAI) ini dikembangkan oleh Slavin. Tipe ini mengkombinasikan keunggulan pembelajaran kooperatif dan pembelajaran individual. Tipe ini dirancang untuk mengatasi kesulitan belajar siswa secara individual. Oleh karena itu kegiatan pembelajarannya lebih banyak digunakan untuk pemecahan masalah, ciri khas pada tipe Team Assisted Individualization ini adalah setiap siswa secara individual belajar materi pembelajaran yang sudah dipersiapkan oleh guru. Hasil belajar individual dibawa ke kelompok-kelompok untuk didiskusikan dan saling dibahas oleh anggota kelompok dan semua anggota kelompok bertanggung jawab atas keseluruhan jawaban sebagai tanggung jawab bersama.

Model pembelajaran kooperatif TAI (Team Assisted Individualization) merupakan salah satu dari pembelajaran kooperatif dengan dibentuk kelompokkelompok kecil dalam kelas yang heterogen, terdiri dari 4-5 peserta didk dalam setiap kelompoknya dan diikuti dengan pemberian bantuan individu bagi peserta didik yang memerlukannya. Keheterogenan kelompok mencakup jenis kelamin, ras, agama, tingkat kemampuan (tinggi, sedang, rendah) dan sebagainya.

Fakta yang terjadi di kelas IV SDN 4 Teluk Melano kecamatan Simpang Hilir Kabupaten Kayong Utara berdasarkan hasil wawancara dengan guru kelas IV pada Senin, 23 Februari2017 di SDN 4
Teluk Melano hasil belajar siswa pada pembelajaran Matematika khususnya pada materi operasi hitung bilangan bulat positif dan negatif tahun pelajaran 2016/2017 sangat rendah. Hal ini dibuktikan berdasarkan hasil evaluasi yang dilakukan guru sekitar $70 \%$ mendapatkan nilai dibawah Kriteria Ketuntasan Minimum yang ditetapkan sekolah untuk pembelajaran Matematika kelas IV yaitu 60.

Salah satu faktor yang menjadi penyebab rendahnya hasil belajar siswa adalah ketidaktepatan penggunaan model atau strategi pembelajaran yang digunakan guru dalam menyampaikan materi yang diajarkan di kelas. Hal ini disebabkan karena guru kurang memahami konsepsi siswa dan tidak membangkitkan perubahan konseptual siswa. Diantara konsep matematika yang sulit dipahami siswa adalah materi-materi operasi penjumlahan dan pengurangan bilangan bulat positif dan negatif. Hal ini disebabkan rendahnya penguasaan siswa tentang fakta-fakta dan konsep operasi hitung bilangan bulat.

Berdasarkan hasil wawancara tersebut disepakati bahwa penulis akan melaksanakan suatu upaya perbaikan pembelajaran di kelas IV SDN 4 Teluk Melano . Dan perbaikan pembelajaran tersebut akan disusun dalam suatu laporan perbaikan pembelajaran mata kuliah Pemantapan Kemampuan Profesional ini.

Masalah yang teridentifikasi saat pelaksanan wawancara awal antara penulis dan guru kelas IV SDN 4 Teluk Melano adalah :

a. Hasil belajar siswa rendah

b. Siswa tidak memahami konsep operasi hitung bilangan bulat

c. Minat belajar siswa rendah terhadap pembelajaran Matematika

Berdasarkan identifikasi masalah diatas penulis menganalisis sumber masalah yang terjadi di kelas IV SDN 4 
Teluk Melano, penyebab rendahnya hasil belajar siswa dan kurangnya siswa memahami konsep operasi bilangan bulat dikarenakan metode yang diterapkan oleh guru saat pembelajaran tidak mampu menanamkan konsep dari materi yang disampaikan. Dalam melaksanakan proses belajar mengajar diperlukan langkahlangkah sistematis untuk mencapai tujuan yang telah ditentukan. Hal yang harus dilakukan dengan menggunakan metode yang cocok dengan kondisi siswa agar siswa dapat berpikir kritis, logis dan dapat memecahkan masalah dengan sikap terbuka, kreatif dan inovatif.

Setelah mengetahui sumber masalah yang terjadi di kelas IV SDN 4 Teluk Melano pada pembelajaran Matematika, maka penulis menawarkan suatu alternativ pemecahan masalah yang sesuai untuk memecahkan masalah pada pembelajaran Matematika tersebut diatas yaitu dengan menerapkan metode kooperatif tipe Team assisted Individualization (TAI). Salah satu ciri pembelajaran kooperatif adalah kemampuan siswa untuk bekerja sama dalam kelompok kecil yang heterogen. Masing-masing anggota kelompok memiliki tugas yang setara karena dalam pembelajaran kooperatif keberhasilan kelompok sangat diperhatikan, maka siswa yang pandai ikut bertanggung jawab membantu temannya yang lemah dalam kelompoknya. Dengan demikian siswa yang pandai dapat mengembangkan kemampuan dan keterampilannya, sedangkan siswa yang lemah akan terbantu dalam memahami permasalahan yang diselesaikan dalam kelompok tersebut.

Adapun rumusan masalah pada perbaikan pembelajaran ini adalah Apakah dengan menerapkan metode kooperatif tipe Team assisted Individualization (TAI) mampu meningkatkan pemahaman siswa terhadap materi operasi hitung bilangan bulat positif dan negatif pada pembelajaran
Matematika Kelas IV SDN 4 Teluk Melano semester genap tahun pelajaran 2016/2017?

Perbaikan pembelajaran ini bertujuan untuk meningkatkan pemahaman siswa terhadap materi operasi hitung bilangan bulat positif dan negatif pada pembelajaran Matematika Kelas IV SDN 4 Teluk Melano semester genap tahun pelajaran 2016/2017 dengan menerapkan metode kooperatif tipe Team assisted Individualization (TAI).

Harapan penulis penelitian perbaikan pembelajaran ini bermanfaat untuk pihakpihak dibawah ini :

1. Manfaat bagi siswa

Agar siswa mendapatkan metode pengajaran yang tepat sehingga siswa mudah untuk memahami konsep pembelajaran Matematika karena dengan metode kooperatif tipe Team assisted Individualization (TAI) siswa akan mudah untuk menguasai konsep Matematika sehingga hasil belajar siswa pun akan meningkat.

a. Manfaat bagi guru; (a) Agar guru mampu menguasai metode-metode pengajaran yang mampu meningkatkan pemahaman siswa.(b) Menambah sisi keilmuan guru sebagai bekal untuk meningkatkan mutu pengajaran.

2. Manfaat bagi sekolah dan dunia pendidikan

Sebagai bahan masukan untuk peningkatan mutu proses belajar mengajar di sekolah dan meningkatkan kualitas pendidikan di Kecamatan Simpang Hilir .

Dalam penelitian ini, keberhasilan penelitian apa bila hasil tes siswa sudah berada dalam tingkat yang ditetapkan. Dalam penelitian ini ketercapaian dapat dilihat dari interval dalam katagori baik ( interval nilai $60-79)$. Berikut ini distribusi interval nilai keberhasilan penelitian : 
Tabel I

Interval Nilai Keberhasilan

Penelitian

\begin{tabular}{lll}
\hline NO & Interval Nilai & \multicolumn{1}{c}{ Kelasifikasi } \\
\hline 1 & $80,00-100$ & Sangat Baik \\
\hline 2 & $60,00-79,00$ & Baik \\
\hline 3 & $40,00-59,00$ & Cukup \\
\hline 4 & $20,00-39,00$ & Kurang \\
\hline 5 & $0,00-19,00$ & Sangat Kurang \\
\hline
\end{tabular}

\section{METODE}

Subjek penelitian pada perbaikan pembelajaran kali ini adalah siswa-siswi beserta guru kelas IV SDN 4 Teluk Melano yang siswanya berjumlah 20 orang anak dengan 11 orang siswa berjenis kelamin laki-laki dan 9 orang siswa berjenis kelami perempuan.

Tempat penelitian adalah SDN 4 Teluk Melano yang terletak di desa Teluk Melano Kecamatan Simpang Hilir Kabupaten Kayong Utara Provinsi Kalimantan Barat. Perbaikan pembelajaran ini dilaksanakan sebanyak 2 siklus dan jadwal pelaksanaan perbaikan tersaji dalam Tabel 2 dibawah ini :

\section{Tabel 2}

Jadwal Penelitian Tindakan

Kelas

SDN 4 Teluk Melano Kecamatan Simpang Hilir

\begin{tabular}{lll}
\hline $\begin{array}{c}\text { Hari, } \\
\text { Tanggal }\end{array}$ & Waktu & $\begin{array}{c}\text { Jenis } \\
\text { Kegiatan }\end{array}$ \\
\hline $\begin{array}{l}\text { Senin, 26 } \\
\text { Februari }\end{array}$ & $07.00-$ & Wawancara \\
2017 & & $\begin{array}{l}\text { Wan } \\
\text { Observasi } \\
\text { Pra Siklus }\end{array}$ \\
\hline Senin, 12 & $07.00-$ & Siklus I \\
Maret & 08.20 & \\
2017 & & \\
\hline Senin, 23 & $07.00-$ & Siklus II \\
April & 08.20 & \\
2017 & & \\
\hline
\end{tabular}

\begin{tabular}{lll}
\hline 10 s.d 23 & Setiap & $\begin{array}{l}\text { Menyusun } \\
\text { Mei }\end{array}$ \\
2017 & Hari & $\begin{array}{l}\text { Laporan } \\
\text { dan seminar }\end{array}$ \\
\hline
\end{tabular}

Pelaksanan perbaikan pembelajaran ini dilaksanakan sebanyak dua siklus dan setiap siklusnya dilaksanakan dengan langkah-langkah seabagai berikut :

a. Tahap Perencanaan

Pada tahap ini penulis dan guru kelas melakukan brainstorming atau berdiskusi untuk menyusun rencana perbaikan pembelajaran dengan metode kooperatif tipe TAI (Team Assisted Individualization). b. Tahap Pelaksanaan

Adapun tahap-tahap dalam model pembelajaran Team Assisted Individualization adalah sebagai berikut :

1. Guru menyiapkan materi bahan ajar yang akan diselesaikan oleh kelompok siswa.

2. Guru memberikan pre-test kepada siswa atau melihat rata-rata nilai harian siswa agar guru mengetahui kelemahan siswa pada bidang tertentu.

3. Guru memberikan materi secara singkat.

4. Guru membentuk kelompokkelompok kecil yang heterogen tetapi harmonis berdasarkan nilai ulangan harian, setiap kelompok 4-5 siswa.

5. Setiap kelompok mengerjakan tugas dari guru berupa LKS yang telah dirancang sendiri sebelumnya, dan guru memberikan bantuan secara individual bagi yang memerlukannya.

6. Ketua kelompok melaporkan keberhasilan kelompoknya dengan mempresentasikan hasil kerjanya dan siap untuk diberi ulangan oleh guru.

7. Guru memberikan Post-test untuk dikerjakan secara individu.

8. Guru menetapkan kelompok terbaik sampai kelompok yang kurang berhasil (jika ada) berdasarkan hasil koreksi. 
9. Guru memberikan penghargaan bagi kelompok yang terbaik sampai yang kurang berhasil (jika ada).

10. Guru memberikan tes formatif sesuai dengan kompetensi yang ditentukan. Tahapan ini dilaksanakan untuk mengetahui segala sesuatu yang terjadi pada saat pelaksaan perbaikan pembelajaran. Baik itu berupa perkembangan postif maupun negative saat pelaksanaan perbaikan. Tahapan ini dilaksanakan dengan mengamati pelaksanaan perbaikan untuk mengetahui tercapai atau tidaknya tujuan dari perbaikan pembelajaran. Adapun instrument untuk melakukan pengamatan di tahapan observasi ini adalah dengan menggunakan lembar observasi.

Setelah mendapatkan hasil pengamatan pada tahapan refleksi ini adalah saat dimana penulis dan guru kelas mengoreksi atau bercermin dari pelaksanaan perbaikan pembelajaran yang dilakukan, sudah sesuaikah pelaksanaan perbaikan dengan apa yang menjadi tujuan dari perbaikan pembelajaran. Apabila belum tercapai tujuan perbaikan pembelajaran maka hendaknya perlu dilakukan lagi perbaikanperbaikan demi tercapainya tujuan di pelaksanaan perbaikan pembelajaran di siklus berikutnya.

Berdasarkan hasil refleksi siklus I apabila masih belum tercapai tujuan perbaikan maka dilaksanakanlah siklus II dengan perbaikan-perbaikan yang direncanakan sesuai dengan prosedur pelaksanan siklus I namun dilakukan dengan lebih baik.

Dalam setiap penelitian diperlukan kemampuan memilih dan menyusun teknik dan alat pengumpul data yang relevan. Kecermatan dalam memilih dan menyusun teknik dan alat pengumpul data sangat berpengaruh pada objektivitas hasil penelitian. Teknik dan alat pengumpulan data yang tepat dalam suatu penelitian akan memungkinkan dicapainya pemecahan masalah secara valid dan reliabel. Teknik pengumpulan data yang digunakan dalam penelitian ini adalah :

Observasi atau pengamatan adalah kemampuan seseorang untuk menggunakan pengamatannya melalui hasil kerja panca indra mata serta dibantu dengan panca indra lainnya. Sedangkan observasi langsung adalah pengamatan yang dilakukan secara langsung pada objek yang di observasikan. Teknik observasi langsung dalam penelitian ini adalah untuk mengetahui keaktifan siswa dalam penerapan model Pembelajaran kooperatif tipe Team Assisted Individualization.

Teknik komunikasi tidak langsung adalah cara mengumpulkan data yang dilakukan dengan mengadakan hubungan tidak langsung atau dengan perantara alat, baik berupa alat yang sudah tersedia maupun alat khusus yang dibuat untuk keperluan itu (Nawawi, 1995:95).

Teknik komunikasi tidak langsung dalam penelitian ini adalah untuk mengetahui respon siswa terhadap penerapan model pembelajaran kooperatif tipe Team Assisted Individualization dengan bantuan Lembar Kerja Siswa pada materi operasi bentuk aljabar khususnya operasi penjumlahan dan pengurangan bentuk aljabar.

Pengukuran berarti usaha untuk mengetahui suatu keadaan berupa kecerdasan, kecakapan nyata (achievement) dalam bidang tertentu, panjang, berat, dan lain-lain dibandingkan dengan norma tertentu (Nawawi, 1995:125). Teknik pengukuran adalah cara mengumpulkan data yang bersifat kuantitatif.

Teknik pengukuran dilakukan untuk mengetahui data hasil belajar siswa pada materi operasi bentuk aljabar. Kegiatan pengukuran yang dimaksud adalah pemberian tes akhir (post-test) berbentuk 
essay. Dalam menghitung hasil tes menggunakan pengskoran dengan memberikan siswa skor setiap butir soal yang dijawab dengan benar sesuai dengan tabel pengskoran dan kunci jawaban. Setelah diperoleh skor hasil tes, siswa diberikan nilai. Adapun perhitungan nilai sebagai berikut:

$$
N=\frac{\text { skoryang diperoleh siswa }}{\text { skor maksimum }} \times 100
$$

Alat pengumpulan data yang digunakan dalam penelitian ini, sebagai berikut:

Lembar pengamatan aktivitas siswa yang digunakan adalah untuk melihat keterlibatan siswa dalam proses pembelajaran. Dalam menilai aktivitas siswa, demi mengurangi subjektivitas maka peneliti berkolaborasi dengan dua orang guru sebagai pengamat. Guru tersebut mengamati aktivitas siswa sejak awal kegiatan pembelajaran sampai guru menutup pelajaran. Adapun kategori pengamatan aktivitas siswa yaitu:

1. Bersikap yang tidak relevan dalam KBM (Tidur, bergurau, sering keluar masuk kelas yang tidak ada urusan, tidak memperhatikan penjelasan guru, membaca buku yang tidak ada hubungannya dengan pelajaran)

2. Mengikuti pelajaran dengan sungguhsungguh.

Membaca dan memahami materi pelajaran pada buku siswa dan LKS.

Berpartisipasi aktif terhadap pembelajaran. Mengerjakan tugas dan mengumpulkannya tepat waktu.

Alat yang digunakan untuk memperoleh data hasil belajar pada materi operasi bentuk aljabar khususnya operasi penjumlahan dan pengurangan bilangan bulat positif dan negatif adalah memberikan tes akhir (post-test) pada kelas eksperimen dan kelas kontrol. Jenis tes yang digunakan tes tertulis dengan bentuk essay.

\section{HASIL DAN PEMBAHASAN Hasil}

Setelah pelaksanaan perbaikan pembelajaran dengan menerapkan metode pembelajaran kooperatif tipe Team Assisted Individualization (TAI) di kelas IV SDN 4 Teluk Melano pada materi operasi hitung bilangan bulat postif dan negative pembelajaran Matematika semester genap tahun pelajaran 2016/2017 sebanyak dua siklus maka didapatlah beberapa hasil yang diperoleh berdasarkan hasil observasi.

Adapun data yang diperoleh terdiri dari 2 jenis data yaitu :

11. Data tingkat keaktifan siswa sebelum dan sesudah pelaksanaan perbaikan pembelajaran dengan metode pembelajaran kooperatif tipe Team Assisted Individualization (TAI).

12. Data Hasil Tes atau Evaluasi siswa sebelum dan sesudah pelaksanaan perbaikan pembelajaran dengan metode pembelajaran kooperatif tipe Team Assisted Individualization (TAI)

Data yang pertama adalah data tingkat keaktifan siswa sebelum dan sesudah pelaksanaan perbaikan pembelajaran dengan metode pembelajaran kooperatif tipe Team Assisted Individualization (TAI). Data tersebut disajikan dalam bentuk tabel dibawah ini :

Tabel 4

Data tingkat tingkat keaktifan siswa prasiklus, siklus I dan siklus II perbaikan pembelajaran dengan metode pembelajaran kooperatif tipe Team Assisted Individualization (TAI) di kelas IV SDN 4 Teluk Melano

\begin{tabular}{ccccc}
\hline & & \multicolumn{3}{c}{ Tingkat keatifan } \\
N & & \multicolumn{3}{c}{ siswa } \\
\cline { 3 - 5 } o & Nama & Pra & Sikl & Sikl \\
& & Sikl & us I & us II \\
& & us & & \\
\hline 1 & Anisa & Aktif & Aktif & Aktif \\
& Nur & & & \\
& Fatonah & & & \\
\hline
\end{tabular}




\begin{tabular}{|c|c|c|c|c|}
\hline 2 & $\begin{array}{l}\text { Andi } \\
\text { Darmawa } \\
\mathrm{n}\end{array}$ & Pasif & Aktif & Aktif \\
\hline 3 & Agustian & Pasif & Pasif & Pasif \\
\hline 4 & Bambang & Aktif & Aktif & Aktif \\
\hline 5 & $\begin{array}{l}\text { Budi } \\
\text { Irawan }\end{array}$ & Pasif & Pasif & Aktif \\
\hline 6 & Bainah & Pasif & Aktif & Aktif \\
\hline 7 & $\begin{array}{l}\text { Cici } \\
\text { Amelia }\end{array}$ & Pasif & Pasif & Pasif \\
\hline 8 & $\begin{array}{l}\text { Cintia } \\
\text { warohma } \\
\mathrm{h} \\
\end{array}$ & Aktif & Aktif & Aktif \\
\hline 9 & $\begin{array}{l}\text { Dedi } \\
\text { Hasiadi }\end{array}$ & Aktif & Aktif & Aktif \\
\hline 10 & $\begin{array}{l}\text { Doni } \\
\text { Drajad }\end{array}$ & Aktif & Aktif & Aktif \\
\hline 11 & $\begin{array}{l}\text { Elia } \\
\text { Febrianti } \\
\end{array}$ & Pasif & Pasif & Pasif \\
\hline 12 & Erlanga & Pasif & Aktif & Aktif \\
\hline 13 & $\begin{array}{l}\text { Erlan } \\
\text { sucipta }\end{array}$ & Pasif & Aktif & Aktif \\
\hline 14 & $\begin{array}{l}\text { Fani } \\
\text { Yurika }\end{array}$ & Pasif & Pasif & Pasif \\
\hline 15 & $\begin{array}{l}\text { Lola } \\
\text { Lolita }\end{array}$ & Pasif & Pasif & Aktif \\
\hline 16 & $\begin{array}{l}\text { Muhamm } \\
\text { ad Nur }\end{array}$ & Aktif & Aktif & Aktif \\
\hline 17 & $\begin{array}{l}\text { Muhamm } \\
\text { ad Aska }\end{array}$ & Pasif & Pasif & Pasif \\
\hline 18 & $\begin{array}{l}\text { Rizki } \\
\text { Aliani }\end{array}$ & Pasif & Pasif & Aktif \\
\hline 19 & Toni & Pasif & Pasif & Aktif \\
\hline 20 & Yuliana & Pasif & Pasif & Aktif \\
\hline
\end{tabular}

Sumber : Hasil Pengamatan prasiklus s.d siklus II Februari s.d April 2017

Data kedua adalah data Hasil Tes atau Evaluasi siswa sebelum dan sesudah pelaksanaan perbaikan pembelajaran dengan metode pembelajaran kooperatif tipe Team Assisted Individualization (TAI). Data ini menentukan tingkat keberhasilan pelaksanaan perbaikan pembelajaran kali ini. Adapun data tersebut tersaji dalam bentuk tabel berikut ini :
Tabel 5

Data Hasil Tes atau Evaluasi siswa kelas IV SDN 03 Munting prasiklus, siklus I dan Siklus II pelaksanaan perbaikan pembelajaran dengan metode pembelajaran kooperatif tipe Team Assisted Individualization (TAI)

\begin{tabular}{|c|c|c|c|c|}
\hline \multirow[b]{2}{*}{$\begin{array}{l}\mathbf{N} \\
\mathbf{o}\end{array}$} & \multirow[b]{2}{*}{ Nama } & \multicolumn{3}{|c|}{$\begin{array}{c}\text { Hasil Evaluasi } \\
\text { Siswa }\end{array}$} \\
\hline & & $\begin{array}{c}\text { Pra } \\
\text { Sikl } \\
\text { us }\end{array}$ & $\begin{array}{l}\text { Sikl } \\
\text { us I }\end{array}$ & $\begin{array}{l}\text { Sikl } \\
\text { us II }\end{array}$ \\
\hline 1 & $\begin{array}{l}\text { Anisa } \\
\text { Nur } \\
\text { Fatonah }\end{array}$ & 65 & 65 & 75 \\
\hline 2 & $\begin{array}{l}\text { Andi } \\
\text { Darmawa } \\
\text { n }\end{array}$ & 55 & 60 & 70 \\
\hline 3 & Agustian & 50 & 55 & 55 \\
\hline 4 & Bambang & 70 & 75 & 80 \\
\hline 5 & $\begin{array}{l}\text { Budi } \\
\text { Irawan }\end{array}$ & 55 & 55 & 60 \\
\hline 6 & Bainah & 55 & 60 & 65 \\
\hline 7 & $\begin{array}{l}\text { Cici } \\
\text { Amelia }\end{array}$ & 50 & 50 & 55 \\
\hline 8 & $\begin{array}{l}\text { Cintia } \\
\text { warohma } \\
\mathrm{h}\end{array}$ & 60 & 65 & 75 \\
\hline 9 & $\begin{array}{l}\text { Dedi } \\
\text { Hasiadi } \\
\end{array}$ & 65 & 70 & 70 \\
\hline 10 & $\begin{array}{l}\text { Doni } \\
\text { Drajad }\end{array}$ & 75 & 75 & 80 \\
\hline 11 & $\begin{array}{l}\text { Elia } \\
\text { Febrianti }\end{array}$ & 55 & 55 & 55 \\
\hline 12 & Erlanga & 50 & 60 & 60 \\
\hline 13 & $\begin{array}{l}\text { Erlan } \\
\text { sucipta }\end{array}$ & 50 & 60 & 65 \\
\hline 14 & $\begin{array}{l}\text { Fani } \\
\text { Yurika }\end{array}$ & 55 & 50 & 55 \\
\hline 15 & $\begin{array}{l}\text { Lola } \\
\text { Lolita }\end{array}$ & 55 & 55 & 60 \\
\hline 16 & $\begin{array}{l}\text { Muhamm } \\
\text { ad Nur }\end{array}$ & 60 & 70 & 70 \\
\hline 17 & $\begin{array}{l}\text { Muhamm } \\
\text { ad Aska }\end{array}$ & 55 & 55 & 55 \\
\hline 18 & $\begin{array}{l}\text { Rizki } \\
\text { Aliani } \\
\end{array}$ & 55 & 55 & 60 \\
\hline 19 & Toni & 50 & 55 & 60 \\
\hline
\end{tabular}


$\begin{array}{lllll}20 & \text { Yuliana } & 50 & 55 & 60\end{array}$

Sumber : Hasil Testprasiklus s.d siklus II

Februari s.d April 2017

\section{PembahasanHasil Penelitian}

Berdasarkan data pelaksanaan

pembelajaran Matematika pra siklus pada tabel 3 mengenai tingkat keaktifan belajar siswa pra siklus atau sebelum diterapkannya pembelajaran dengan menggunakan metode pembelajaran kooperatif tipe Team Assisted Individualization (TAI) pada pembelajaran Matematika kelas IV adalah sekitar 6 orang siswa atau sekitar $30 \%$ dari 20 orang siswa yang aktifitasnya tergolong aktif saat pembelajaran belajar dan sekitar 14 orang atau sekitar $70 \%$ dari 20 orang siswa yang saat pembelajararn berlangsung tergolong pasif. Hal ini dikarenakan metode yang dipakai oleh guru sebelum perbaikan pembelajaran sangat membosankan sehingga siswa tidak memiliki gairah belajar yang tinggi sehingga hal ini berhubungan dengan tingkat keaktifan belajar siswa sangat rendah.

Setelah dilaksanakannya perbaikan pembelajaran pada siklus I tingkat keaktifan siswa saat pelaksanaan pembelajaran mulai mengalami peningkatan dari yang sebelumnya hanya $30 \%$ dari 20 orang siswa yang aktif di kelas meningkat $20 \%$ menjadi $50 \%$ siswa yang aktif saat pembelajaran. Dan dari yang sebelumnya ada $70 \%$ dari 20 orang siswa yang pasif saat pembelajaran berkurang sebanyak $20 \%$ sehingga hanya tinggal $50 \%$ siswa yang pasif saat pembelajaran

Hasil ini tentunya belum memuaskan dan belum sesuai dengan tujuan perbaikan walupun tingkat keaktifan siswa mulai meningkat walaupun jumlahnya masih sangat kecil. Untuk itu dilaksanakanlah siklus II, pada tabel 3 terdapat data tingkat keaktifan siswa pada pelaksanaan pembelajaran siklus II. Pada siklus I persentase jumlah siswa yang aktif sekitar $50 \%$ pada siklus II meningkat menjadi $70 \%$ dari 20 orang siswa yang aktif saat pelaksanaan pembelajaran. Pada siklus I terdapat $50 \%$ siswa yang pasif saat pembelajaran pada siklus II berkurang $20 \%$ menjadi hanya tinggal $30 \%$ siswa yang pasif saat pembelajaran setelah diterapkannya perbaikan pembelajaran kooperatif tipe Team Assisted Individualization (TAI) pada siklus II.

Tingkat aktifitas belajar ini berpengaruh terhadap tingkat pemahaman siswa, siswa yang antusias saat pembelajaran maka akan memiliki tingkat pemahaman yang tinggi pula terhadap materi yang disampaikan hal ini dikarenakan rasa keingin tahuan yang tinggi mendorong mereka untuk menerima ilmu dengan baik. Berdasarkan tabel 4 menunjukan data hasil tes atau evaluasi siswa sebelum dan sesudah pelaksanaan perbaikan pembelajaran dengan metode pembelajaran kooperatif tipe Team Assisted Individualization (TAI) data ini yang menentukan mampu atau tidaknya metode pembelajaran kooperatif tipe Team Assisted Individualization (TAI) meningkatkan pemahaman siswa kelas IV SDN 4 Teluk Melano . Pada tabel tersebut sebelum diterapkannya pembelajaran dengan metode kooperatif tipe Team Assisted Individualization (TAI) atau pra siklus jumlah siswa yang mendapatkan nilai diatas KKM hanya 6 orang hal ini sama dengan $30 \%$ dari 20 orang siswa yang mendapatkan nilai diatas KKM. Dan siswanya 14 orang atau sama dengan $70 \%$ dari 20 orang siswa yang mendapatkan nilai dibawah KKM.

Setelah dilaksanakan perbaikan pembelajaran siklus I jumlah siswa yang mendapatkan nilai diatas KKM setelah dievaluasi meningkat menjadi 10 orang atau sama dengan $50 \%$ dari 20 orang 
siswa. Dan terjadi penurunan pada jumlah siswa yang mendapatkan nilai dibawah KKM yang sebelumnya berjumlah 14 orang berkurang menjadi 10 orang yang mendapatkan nilai dibawah KKM hal ini sama dengan $50 \%$ dari 20 orang siswa yang mendapatkan nilai dibawah KKM.

Pada Siklus II berdasarkan tabel 4 jumlah siswa yang mendapatkan nilai diatas KKM pada perbaikan pembelajaran siklus II meningkat dari jumlah yang sebelumnya 10 orang menjadi 14 orang mendapatkan nilai diatas KKM. Pada siklus II ini terjadi pula penurunan jumlah siswa yang mendapatkan nilai dibawah KKM setelah dievaluasi yaitu hanya tinggal 6 orang atau sekitar $30 \%$ dari 20 orang siswa.

Dari pembahasan data diatas penulis mendapatkan bukti nyata bahwa dengan menerapkan metode pembelajaran kooperatif tipe Team Assisted Individualization (TAI) pada materi operasi hitung bilangan bulat positif dan negative pembelajaran Matematika mampu meningkatkan pemahaman siswa kelas IV SDN 4 Teluk Melano semester genap tahun pelajaran 2016/2017. Hal ini dikarenakan metode ini mampu membuat siswa aktif saat pembelajaran dikelas karena dilakukan secara berkelompok. Dan siswa terbiasa mengkontruksi sendiri konsep materi operasi hitung bilangan bulat postif dan negative.

\section{KESIMPULAN DAN SARAN \\ Kesimpulan}

Berdasarkan hasil perbaikan pembelajaran yang dilaksanakan pada kelas IV SDN 4 Teluk Melano penulis mencoba menarik beberapa kesimpulan. Adapun kesimpulan yang dapat ditarik penulis adalah sebagai berikut :

1. Dengan menerapkan metode pembelajaran kooperatif tipe Team
Assisted Individualization (TAI) keaktifan belajar siswa meningkat.

2. Dengan menerapkan pembelajaran kooperatif tipe Team Assisted Individualization (TAI) pemahaman siswa terhadap konsep operasi hitung bilangan bulat postif dan negatif meningkat.

3. Metode kooperatif sangat efektif diterapkan untuk penyampaian materi pembelajaran Matematika yang merupakan pembelajaran yang menuntut penguasaan konsep, bukan hapalan.

\section{Saran}

Adapun saran dan tindak lanjut yang dapat diberikan penulis pada perbaikan pembelajaran kali ini adalah :

1. Metode pembelajaran kooperatif tipe Team Assisted Individualization (TAI) sangat tepat untuk diterapakan pada pembelajaran Matematika

2. Guru sebagai penyampai ilmu harus mampu menggunakan metode yang tepat dalam melaksanakan pembelajaran di kelas. Karena metode yang dipergunakan harus sesuai dengan tingkat kesukaran dan jenis materi pembelajaran

3. Guru harus lebih banyak lagi belajar menggunakan metode yang variatif untuk mencegah kebosanan.

\section{DAFTAR RUJUKAN}

Abror, Rahman. (1993). Psikologi Pendidikan. Yogyakarta: Tiara Wacana.

Arikunto. S. ( 1990 ). Manajemen Penelitian. Jakarta : Rineka Cipta.

Azhar, M.L. (1993). Proses Belajar Mengajar Pola CBSA. Surabaya: Usaha Offset Printing. 
Baharuddin, dkk. (2007). Teori Belajar dan Pembelajaran. Jogjakarta: Ar-Ruzz Media.

Rosadila. (2007). Penerapan Pendekatan Team Assisted Individualization (TAI) Pada Kelas XI SMA Negeri 8 Pontianak: STKIP PGRI.
Rusyani, tabrani dkk. (1989). Pendekatan Dalam Proses Belajar Mengajar. Bandung: FKIP Uninus

Antono, dkk (2006). Buku Matematika IV SD/MI, Jakarta: Erlangga

Purnomo, J. (2010). Mahir Matematika kela IV SD, Surabaya : Sinar Pustaka 